\title{
Multinational Performance and Risk Management Effects Capital Structure Contingencies
}

\author{
Andersen, Torben Juul
}

Document Version

Final published version

Publication date:

2008

\section{License \\ CC BY-NC-ND}

Citation for published version (APA):

Andersen, T. J. (2008). Multinational Performance and Risk Management Effects: Capital Structure

Contingencies. Center for Strategic Management and Globalization. SMG Working Paper No. 8/2008

Link to publication in CBS Research Portal

\section{General rights}

Copyright and moral rights for the publications made accessible in the public portal are retained by the authors and/or other copyright owners and it is a condition of accessing publications that users recognise and abide by the legal requirements associated with these rights.

Take down policy

If you believe that this document breaches copyright please contact us (research.lib@cbs.dk) providing details, and we will remove access to the work immediately and investigate your claim. 
Multinational Performance and Risk Management Effects: Capital Structure Contingencies

\author{
Torben Juul Andersen
}

SMG WP 8/2008

February, 2008 
SMG Working Paper No. 8/2008

February, 2008

ISBN: 978-87-91815-21-8

Center for Strategic Management and Globalization Copenhagen Business School

Porcelænshaven 24

2000 Frederiksberg

Denmark

www.cbs.dk/smg 


\title{
Multinational Performance and Risk Management Effects: Capital Structure Contingencies
}

\author{
Torben Juul Andersen \\ Copenhagen Business School \\ Center for Strategic Management \& Globalization \\ Porcelænshaven 24, 1.53 \\ DK-2000 Frederiksberg \\ Denmark
}

Phone: +45 3815-2514

Email: ta.smg@cbs.dk

February 2008 


\title{
Multinational Performance and Risk Management Effects: Capital Structure Contingencies
}

\begin{abstract}
Multinational enterprise provides access to a diverse resource base that may support options related business initiatives and operational flexibilities with a potential to improve performance and risk management capabilities. Hence, multinationality should be associated with strategic responsiveness as real option structures allow the corporation to exploit new initiatives and pursue alternative actions. This, in turn should improve economic performance and risk management capabilities as corporate activities are adapted and new initiatives introduced in response to changing global conditions. The analyses of a cross-sectional sample comprising 1357 multinational firms during 1996-2000 partially support the proposed performance and risk management effects but also raise issues for further study.
\end{abstract}

Keywords: Economic performance, Financial leverage, Multinationality, Real options, Risk management 


\section{INTRODUCTION}

The multinational enterprise has access to an extended range of tangible and intangible resources that provide the organization with incremental strategic opportunity (Prahalad and Doz, 1987; Yip, 1995; Barttlet and Ghoshal, 1998; Govindarajan and Gupta, 2001). It is argued that international resources can form the basis for options related operational flexibilities with potential performance and risk management advantages (Kogut, 1985; Bowman and Hurry, 1993; Kogut and Kulatilaka, 1994). This perspective has been extended to argue that diverse multinational knowledge can be recombined to create responsive business initiatives (Kogut and Zander, 1993; Grant, 1996; Foss and Pedersen, 2002; Andersen and Foss, 2005). Hence, the multinational enterprise should exhibit a higher degree of responsiveness in strategic decision-making as real option structures extend the ability to exploit new initiatives and pursue alternative actions in response to changing global conditions, which in turn should improve economic performance and risk management capabilities. However, the exploitation of underlying real option structures requires a certain financial buffer and, therefore, lower financial leverage is likely to enhance the proposed performance effects incorporating capital structure as a central strategic decision parameter (Balakrishnan and Fox, 1993). This study investigates a crosssectional sample of 1357 multinational firms during the period 1996-2000 and finds some evidence in support of the proposed performance and risk management effects.

The paper outlines the proposed advantages associated with multinational enterprise and provides a brief overview of the basic finance and strategic management literatures on capital structure and risk management. Aspects of agency theory, transaction cost economics, the resource-based view, and real options reasoning are integrated in the development of associated hypotheses. Following this, the paper describes the empirical study performed to test the hypotheses and presents outcomes from the analyses. Finally, the findings are discussed and venues for further research efforts are proposed. 


\section{THEORY AND LITERATURE}

\section{Multinational performance}

The wider array of business opportunities across different national markets should provide flexibility to firms that maintain a multinational organization and thereby increase the ability to respond to changing environmental conditions. It has specifically been argued that operational flexibilities can allow the corporation to reposition and restructure in response to changes in international price relations by shifting activities between national entities controlled by the multinational enterprise (Kogut, 1985; Rangan, 1998). The ability to switch business activities across international productive assets can be conceived as a particular real option structure where the value of the implied flexibility can be determined on the basis of option pricing theory (Kogut and Kulatilaka, 1994). The flexibility of a multinational organization should allow the corporation to mitigate effects of major economic exposures, e.g., associated with changes in relative demand conditions and factor costs across national environments (Allen and Pantzalis, 1996; Kogut and Chang, 1996).

Furthermore, a multinational organization may provide opportunities to exchange diverse knowledge between national environments where different insights and perspectives enhance the ability to innovate and develop new growth options (Kogut and Zander, 1992, 1993; Grant, 1996). So, multinationality might be linked to the innovative capacity of multinational diversity and forming the basis for strategic opportunity that can increase maneuverability in an uncertain global environment (e.g., Mang, 1998; Desouza and Evaristo, 2003; Andersen and Foss, 2005). This particular view of multinationality has some resemblance to innovation strategy as the firm expends resources towards the creation of a more innovative multinational organization. In either case, the multinational organization should increase flexibility and strategic responsiveness and thereby improve economic performance.

\section{Risk management effects}

The presence of real options based flexibilities should enhance effective risk management practices that diminish earnings volatility and thereby reduce the costs associated with potential financial distress. If 
the volatility of the firm's cash flows is reduced and the firm maintains a certain financial cushion in the form liquid financial assets and committed credit facilities then funding should always be available for positive NPV projects, all the while the lower performance volatility will reduce the firm's average cost of capital. To the extent an organization is able to manage uncertainties imposed by dynamic global conditions potential under investment problems would be reduced resulting in higher earnings (Froot, Scharfstein and Stein, 1993, 1994). Hence, risk management can be extended to include a real options perspective where firms are able to develop opportunities and claims on the future that can be evaluated based of assumptions about underlying risk factors (Leiblein, 2003). The real option structures differ from financial options in the way the option value is tied to idiosyncratic conditions in the firm (McGrath, 1997) as well as firm specific strategy processes may differ in unique ways that influence the firm's ability to exploit the options. Hence, the presence of real options should be able to enhance sustainable value creation since they are based on firm specific assets and processes not readily available in public markets (Barney, 1991).

\section{Financial leverage}

Modigliani and Miller (1958) showed that under simplifying conditions of no taxes, transaction costs, or bankruptcy costs, the value of the firm will be independent of capital structure. However, when taxes interfere and interest expenses are tax deductable, the optimal capital structure will be determined by a trade-off between increased bankruptcy risk from a higher debt load and the tax advantage of debt (Modigliani and Miller, 1963). Under conditions of asymmetric information where managers in the firm know more about prospective projects than investors in the market, the capital structure may be determined in accordance with a pecking order whereby internal sources are used to fund good projects first while debt only is assumed to finance less attractive marginal projects (Myers and Majluf, 1984). The trade-off perspective results in a proportional relationship between economic performance and leverage whereas the pecking order perspective is more indeterminate. 
Potential agency costs associated with equity financing derive from the possibility that managers divert productive resources to employment benefits with limited returns to shareholders (Jensen and Meckling, 1976). This discrepancy between management and shareholder interests can have implications for investment decisions. Management could issue equity to pursue their own objectives and engage the firm in questionable projects that would lead to over investment (Jensen, 1986; Stulz, 1990). Increasing the debt load might arguably solve this problem but excessive financial leverage can also create an under investment problem as debt service payments limit the discretion to engage in new business initiatives (Myers, 1977).

Ward (1993) distinguished between business risk imposed by uncertainty imposed by the competitive environment and financial risk associated with the positions of funds providers (lenders, investors, and shareholders) and funds users (firm management). From a management perspective debt is riskier because regular debt service payments are enforceable whereas equity is less risky. Conversely, equity is riskier to investing shareholders because it constitutes residual claims that serve as a buffer to ensure the servicing of senior debt obligations. Hence, firm management should be inclined to use equity funding for ventures with high business risk because it provides a higher financial buffer to cope with an uncertain competitive environment. Conversely, debt instruments would be better suited to fund relatively stable business activities where the need for a financial buffer is lower, i.e., there should arguably be an inverse relationship between business risk and financial leverage. This phenomenon has been identified in some empirical studies using different conceptualizations of business risk, such as, variance in sales growth (Thies and Klock, 1992) and volatility of demand (Chung, 1993).

\section{Environmental dynamism}

From a resource-based view, sustainable competitive advantage reflected in excess rents or Shumpeterian returns can be obtained by deploying valuable, rare, inimitable, and organized firm specific assets (Barney, 1991). This implies that firms operating in dynamic environments must pursue innovative behaviors and engage in more risky initiative to create superior performance, which will 
impose a higher level of business risk on corporate activities and call for lower financial leverage. Transaction cost economics suggest that transaction costs are lower when they are carried out on the basis of standardized assets whereas transaction costs are higher in the case of firm specific assets (Williamson, 1988). Therefore, high asset specificity makes internal hierarchical coordination more economical compared to market clearance of transactions. A higher equity base reflects internal hierarchical control whereas higher leverage imposes market discipline on organizational activities. Hence, equity should be the preferred source of financing when asset specificity is high (Harris, 1994). Since dynamic environments arguably require deployment of assets with high specificity, equity funding should lower transaction costs in this situation and, therefore, constitute a more suitable funding alternative. Conversely, debt should be more appropriate to fund assets with a lower specificity as they pertain to relatively stable environments.

From the perspective of agency theory, debt can be used as a disciplinary tool to ensure that managers give preference to wealth creation for the equity holders (Jensen, 1986, 1989). In this set-up, lenders are the prime governance constituents because debt payment obligations and restrictive covenants make it more difficult for indebted firms to engage in risky peripheral business initiatives. Conversely, it will also reduce the number of strategic opportunities available to the firm and thereby makes it more difficult to maneuver in dynamic market environments. In other words, debt can become too restrictive for firms operating in rapidly changing industries that require a high degree of strategic responsiveness. Together, these arguments imply that the appropriate financial strategy in dynamic environments is to reduce leverage to economize on transaction cost and ensure flexibility and responsiveness.

The resource-based view argues that contemporary dynamic environments characterized by ongoing innovation require strategies driven by firm specific assets and processes (Barney, 1991). The transaction cost perspective further argues that the idiosyncratic assets employed in innovative initiatives makes equity financing more economical and constitutes a better market signal (Santorelli, 1991; Banerjee and Wihlborg, 2003). Since information asymmetry between internal managers and 
external investors is higher in innovative and $R \& D$ intensive organizations, the level of financial slack also tends to increase (Opler and Titman, 1994; Opler, Pinkowitz, Stulz and Williamson, 1999). Hence, to succeed with an innovation strategy in dynamic environments it is necessary to maintain a certain financial buffer to ensure sufficient funding sources for development investments, product launches, and ongoing knowledge expansion (O’Brien, 2003). The empirical evidence seems to confirm the existence of such an inverse relationship between R\&D intensity and leverage (Titman and Wessels, 1988; Opler and Titman, 1994; Hovakimian, Opler and Titman, 2001).

\section{Risk management perspectives}

Risk management practices have evolved in conjunction with the growth in derivative instruments and new product enhancements bridging the conventional insurance and capital markets (Rawls and Smithson, 1990; Shimpi, 1999; Colarossi, 2001). Many of the risk management techniques have been developed in the financial industry, which by definition constitutes risk management business (e.g., Saunders, 2003). Effective risk management practices dampen the variability in periodic earnings and thereby reduce the average cost of funding. The availability of more favorably priced funding eliminates potential under investment problems, which constitutes a basic argument for financial hedging (Froot, Scharfstein and Stein, 1993, 1994). The 'insurative’ model incorporating financial derivatives, insurance contracts, and equity funding as residual claims illustrates that capital structure decisions and risk management are intertwined issues (Shimpi, 1999). Equity is needed as a cushion against adverse economic outcomes to assure stakeholders about the strength, stability, and soundness of the firm as a going concern. Engagement in insurance and derivatives serves the same purpose by transferring exposures beyond the discretionary control of management to financial market participants and, therefore, constitute important sources of financial capital (Culp, 2002).

Miller (1998) argues that it is important to improve risk management capabilities relating to firm specific exposures because many stakeholders are unable to diversify investments geared specifically to the firm in buyer and supplier relationships, business partnerships, management and 
employment contracts, etc. Since competitive exposures often require strategic responses that are unique to the firm there is a limit to how far conventional risk-transfer instruments can accomplish this task. Hence, a firm may try to invest in the creation of real option structures to deal with these risk factors and thereby improve the ability to respond to competitive exposures.

\section{HYPOTHESES}

The literature review suggests that a possible two-thronged theoretical rationale for performance effects of multinationality is at play, one effect associated with operational flexibilities based on tangible resources and another effect associated with innovative behavior based on intangible resources. The first effect should apply to firms with geographically dispersed operating assets, e.g., in production, distribution, and retailing activities. The ability to switch sourcing, production, and sales across different currency jurisdictions allows a multinational enterprise to take advantage of favorable foreign exchange rate regimes and increase responsiveness to exploit changes in international demand and price relations (Kogut and Kulatilaka, 1994; Kogut and Chang, 1996). The latter effect should be relevant to firms engaging in more knowledge intensive business activities, e.g., a corporate emphasis on after sales services, new product innovations, or operations focused directly in service oriented industries (Contractor, Kundu and Hsu, 2003). An innovation strategy is associated with the creation of new growth options for the firm including potential product introductions and process improvements (Myers, 1984). The creation of real options is associated with recognition of inherent flexibilities embedded in existing resources that can enable the firm to modify its strategic position (Bowman and Hurry, 1993). The implied portfolio of real option structures provide the firm with a wider choice of alternative strategic actions and an ability to time new responsive strategic moves better to the firm's economic advantage (Leuhrman, 1998). This rationale leads to the following hypothesis.

HYPOTHESIS 1: A higher degree of multinationality is positively associated with economic performance 
Hence, multinationality can be conceived as a form of innovation strategy where a diverse international resource base is used to create growth options that extend the strategic opportunities available across different national markets (Grant, 1996; Foss and Pedersen, 2002). The embedded strategic opportunities can be exploited to the firm's economic advantage but the development of innovative initiatives that lead to new growth options requires a certain level of organizational slack as does the ability to exploit them when conditions are favorable. Firms need a certain financial buffer as reflected in a stronger capital base to deal with the higher specificity of firm assets required to create excess rents in dynamic global environments (Harris, 1994; Simerly and Li, 2000) all the while excessive leverage can cause under investment problems (Myers, 1977). The financial buffer is needed to ensure availability of funds for research efforts, new product launches, and on-going development of knowledge based capabilities (O’Brien, 2003). This argues for the following hypothesis.

\section{HYPOTHESIS 2: The positive association between multinationality and economic performance is negatively moderated by the level of financial leverage}

A multinational enterprise with operating assets dispersed globally can create flexibilities in the form of switching options that enable the firm to react to changing financial, economic, and competitive conditions across major market areas (Kogut and Kulatilaka, 1994). The increased operational flexibility should improve the ability to modify cash flow streams in response to major shifts in international price relationships and thereby counter effects of exogenous economic risk factors (Miller, 1997). Within a flexible multinational structure with a larger portfolio of innovative initiatives and growth options the strategic maneuverability is enhanced (Leuhrman, 1998). The wider choice of alternative strategic actions should improve the ability to manage risk exposures over time because it enables the firm to avoid downside risks and thereby smooth the corporate earnings development. On the other hand, building a multinational enterprise spanning diverse national settings increases organizational complexity and extends coordination requirements (Prahalad and Doz, 1987; Bartlett and Ghoshal, 
1998), imposes additional resource demands (Christophe, 1996), and exposes the organization to new risk factors deriving from multidimensional national diversities commonly referred to as 'liabilities of foreignness' (Zaheer, 1995). In other words, different aspects of multinational enterprise provide arguments for two opposing risk management effects associated with multinational enterprise. Here we emphasize the potential for positive risk management effects of underlying real option structures, and propose the following hypothesis.

HYPOTHESIS 3: A higher degree of multinationality is positively associated with risk management performance

The subsequent section describes an empirical study devised to test these hypotheses and further explore the relationships between multinationality, economic performance, capital structure decisions, and risk management effects.

\section{METHODS}

\section{Sources}

The empirical study is based on a sample consisting of large US firms operating across industries identified by their four-digit SIC-codes registered in Compustat. The sample includes the Fortune 500 companies, the Stern-Stewart Performance Top 1000 companies, and the 1000 largest companies in Compustat determined by market capitalization reported as of May 2001. These sources resulted in a total sample of 1357 companies where financial data are available from Compustat. Information about overseas establishments was obtained from America’s Corporate Families and International Affiliates (Dun \& Bradstreet), Vol. III, 2001. 


\section{Variables}

\section{Organizational performance}

Economic performance was measured by two financial ratios, return on assets and return on investment. Return on assets (ROA) is determined as income before extraordinary items divided by total assets (including current assets, net property, plant and equipment, and other non-current assets). Return on investment (ROI) is determined as income before extraordinary items divided by total invested capital (including total long term debt, preferred stock, minority interest, and total common equity). The financial ratios were averaged over the 5-year period 1996-2000 to avoid influences by temporary annual events. Economic performance is defined as reported results as opposed to markets returns that are influenced by investor behaviors and therefore could lead to skewed performance indicators in the inflated market of the late 1990s (Schleifer, 2000).

\section{Financial leverage}

The financial leverage measure is determined as the ratio of debt to equity including all fixed charge debt obligations and preferred stock divided by common equity. The debt to equity ratio was averaged

over the 5-year period 1996-2000 to avoid spurious effects. The study assessed leverage based on realized economic performance rather than market value of equity, which is influenced by investor expectations about the firm’s future financial performance and general market prospects.

\section{Environmental dynamism}

Environmental dynamism is determined by a standardized instability index calculated as the standard error of the regression coefficient in the regression of total industry sales over the 5-year period 19962000 against a time variable divided by the average value of industry sales (Dess and Beard, 1984; Keats and Hitt, 1988). To obtain consistent measures of environmental dynamism, the instability indices were calculated on the basis of aggregate industry data by two-digit SIC codes identified in the Compustat database and were not limited to the sampled firms. 


\section{Multinationality}

The multinationality measure is determined on the basis of number of foreign subsidiaries and countries in which the subsidiaries operate (Kogut and Singh, 1988). It was calculated as the natural logarithm of one plus the number of foreign subsidiaries the firm has and the natural logarithm of one plus the number of countries in which the firm has subsidiaries. The two numbers were added to indicate diversity in term of national environments and operational knowledge. The natural logarithm was adopted to achieve normality and adjust for skewness in the data.

\section{Risk management}

The risk management measure is determined as the extent to which the firm copes with uncertainties in the external environment and is able to stabilize the firm's earnings development. The risk management measure was calculated as the standard deviation in sales, reflecting general business uncertainty divided by the standard deviation in economic performance, indicating earnings variability after the firm has adapted activities in response to changing conditions. The measure was based on the two economic performance indicators employed. Hence, one risk management measure divides the standard deviation of the firm's net sales during 1996-2000 by the standard deviation of the firm's ROA during the same period while another risk management measure divides the standard deviation of the firm's net sales by the standard deviation of the firm's ROI. The two ratios constitute direct indicators of the organization's ability to adapt activities in view of exogenous risk factors and manage the associated exposures to reduce variability in economic performance.

\section{Analyses}

The hypotheses were tested in multiple regression analyses using the economic performance and risk management measures as the dependent variables. One set of regressions used the two economic performance measures, i.e., 5-year average ROA and 5-year average ROI, as dependent variables and 
measures of multinationality, financial leverage, environmental dynamism and their interaction terms as independent variables. Another set of regressions used the two risk management measures, i.e., based on variability in ROA and ROI respectively as dependent variable and multinationality, financial leverage, environmental dynamism and their interactions as independent variables. Various control variables were considered in the regressions including organizational size, agency and transaction cost biases, and market-to-book valuations.

Organizational size reflects past economic success and, therefore, may represent availability of slack resource that could affect the ability to respond to exogenous change and the choice of capital structure (Aldrich and Auster, 1986; Aldrich, 1999). Organizational size was included in the regressions measured as the natural logarithm of total assets to correct for positive skew in the data. Potential exposures to agency and transaction cost problems could affect capital structure decisions (Simerli and $\mathrm{Li}$, 2000). Hence, we included a firm dummy to indicate firms with returns on capital below -2.5 percent, with return on capital calculated as operating profit after tax divided by outstanding capital at the beginning of the year, and capital growth below 25 percent. Firms in this subgroup have not been able to create returns in excess of the cost of capital during the period and are, therefore, likely to display severe agency and transaction cost problems. The dummy variable was assigned a value of 1 for firms belonging to the subgroup while all other firms were given a value of 0 . The market to book ratio indicates the potential issue price of new equity in the firm, which might influence capital structure decisions (Hovakimian, Opler and Titman, 2001). The market to book ratio has also been identified as a significant predictor of market returns (Fama and French, 1992, 1993) and hence could influence the economic performance measures used as dependent variables in the regressions.

The regression analyses were tested for possible outlier effects and multicollinearity. Data sets with large prediction errors were excluded from the sample in a sequential manner to observe potential changes in regression coefficients. The final sample excluded 34 observations where prediction errors exceeded three times the standard deviation while no material changes were observed in regression coefficients compared to calculations based on the full sample. No multicollinearity problems were 
identified and VIF factors did not reach levels indicating potential multicollinearity problems (Kleinbaum, Kupper, Muller and Nizam, 1998; Lomax, 1992).

\section{RESULTS}

Statistics and correlation coefficients on the sampled datasets are reported in Table 1.

Please insert Table 1 about here.

Multinationality is significantly positively correlated with the two economic performance measures and the two risk management measures (Table 1). Financial leverage is negatively correlated with economic performance while the interaction between multinationality and leverage has no significant correlation to the economic performance measures.

The results of the two sets of regression analyses are reported in Tables 2 and 3.

Please insert Table 2 about here.

Please insert Table 3 about here.

Multinationality has significant positive relationships to both economic performance measures (Table 2), which provides support for hypothesis 1, i.e., multinational enterprise is associated with superior economic performance. The interaction terms between multinationality and financial leverage has a significant negative relationship to both economic performance measures (Table 2), which provides support for hypothesis 2. Hence, the pursuit of multinational enterprise while maintaining low financial leverage and a relatively high capital base is associated with superior economic performance. However, multinationality has a significant negative relationship to the risk management measure on the basis of 
average ROA (Table 3) and, therefore, fails to support hypothesis 3. In fact, the regression result contradicts the hypothesized relationship by finding a significant relationship in the opposite direction, i.e., the incremental risk exposures associated with multinationality seem to exceed the potential for direct risk management benefits from multinational enterprise.

\section{DISCUSSION}

The regression analyses provide support for hypotheses 1 and 2 and thereby give some credence to the underlying theoretical rationales founded in real options reasoning. Initial analyses of industry specific sub-samples suggest that these relationships are retained across most industrial environments. Hence, the evidence seems to indicate that multinational enterprise is associated with higher economic performance because a diverse global resource base provides the basis for operational flexibilities that increase the ability exploit changes in international demand conditions and price relations in factor markets, products markets, and financial markets (Kogut and Kulatilaka, 1994; Kogut and Chang, 1996). Furthermore, the diversity in global sourcing channels, national market practices, and access to human resources can provide strategic opportunities that otherwise would be unavailable to domestic firms (Kogut and Zander, 1993; Bartlett and Ghoshal, 1998; Foss and Pedersen, 2002). Adopting a real options perspective can help explain why capital structure decisions may affect the effectiveness of multinational enterprise as a financial buffer is needed to take advantage of operational flexibilities and growth options that increase the firm's strategic responsiveness (Myers, 1977; Bettis and Hitt, 1995; Miller, 1998).

Nonetheless, more research is needed to uncover how multinational enterprise and capital structure decisions interact and spill over into improved economic performance. It may be argued that a reverse causality is at play and that high performing well capitalized corporations are the ones that decide to pursue internationalization of activities. Whereas this argument could pertain to corporations operating out of rather small home markets, as might be the case in most European countries, it does not carry the same weight for firms headquartered in the US. The current sample is solely comprised of US 
based companies where the domestic market offers a large potential with many alternative venues for growth and is, therefore, less likely to represent a growth induced internationalization path. Furthermore, high performing firms only engage in new business activities that offer a return in excess of the firm's average cost of capital, i.e., they avoid agency and transaction cost biases. Since the regression analyses control for firms that fail to follow such practices, the positive relationship between multinationality and economic performance is likely to reflect genuine and sound managerial investment and funding decisions. The multinational enterprise needs an equity based financial buffer to ensure that funding is available to develop real option structures and to invest in the execution of them when market circumstances warrant it (Dixit and Pindyck, 1994; Leuhrman, 1998). The ability to create a real options portfolio through global innovation and learning requires a certain amount of slack resources and is, therefore, likely to have an inverse relationship to financial leverage.

These results partially contradict previously reported findings that based on an options logic failed to find the predicted negative association between multinational enterprise and downside risk ${ }^{1}$ (Reuer and Leiblein, 2000). One reason could be that Reuer and Leiblein's (2000) study only comprised a somewhat smaller sample of manufacturing firms and excluded more knowledge intensive service industries (Contractor, Kundu and Hsu, 2003). However, initial analyses of industry sub-samples extracted from the current dataset indicate that manufacturing, wholesale and retail, and services seem to reproduce results across these major industrial environments. Hence, the new findings could be explained by the more recent data sampling focused on larger firms that, e.g., exclude smaller and more risky start-up ventures. It could also be partially explained by the larger sample size that increases the power of statistical significance tests.

The correlation coefficient between multinationality and environmental dynamism is negative (Table 1) and, therefore, does not seem to indicate that multinational expansion is related to specifically dynamic business environments. However, the regression analyses show that multinational expansion in

\footnotetext{
${ }^{1}$ Since downside risk constitutes some measure of below average performance over a given time-period, a negative relationship between downside risk and multinationality corresponds to a positive relationship between economic performance and multinationality.
} 
dynamic environments is associated with significantly lower economic performance (Table 2). This may tell us that firms operating in relatively dynamic industries characterized by innovative behaviors are exposed to dual challenges of global complexity and dynamic business conditions. Furthermore, the regression analyses indicate that corporations operating in dynamic environments achieve higher performance levels when financial leverage is low (Table 2), which is consistent with previous studies (Simerli and Li, 2000). Hence, we are back to square one, i.e., multinational enterprise is associated with higher economic performance when the firm has lower financial leverage, and while multinational enterprises that operate in dynamic industries will display relatively lower performance, they will improve performance outcomes if they have lower financial leverage. This rationale is consistent with the idea that a global enterprise with higher business risk should impose a higher equity ratio to create a sufficient financial buffer to absorb associated performance volatility (Ward, 1993). Similarly, these firms need a stronger equity position to deal with the higher specificity of firm assets required to create excess rents in the dynamic global competitive contexts (Harris, 1994).

The negative relationship between risk management performance and multinationality (Table 3) represents a conundrum between the potential risk management benefits and costs associated with multinational expansion and there is some indication that multinationality can be associated with increasing business risk (Reeb, Kwok and Baek, 1998). Hence, this study demonstrates that there is no direct positive risk management effect associated with multinationality as hypothesized. However, additional regression analyses indicate that both multinationality and risk management has positive direct relationships to economic performance and, more interestingly, the interaction between the two also indicates a positive performance relationship. In other words, there seems to be a venue open for further studies investigating the circumstances under which multinational enterprises with effective risk management competencies can achieve superior performance. This approach may call for more detailed qualitative studies of firms that can be identified on the basis of the preliminary results obtained from the current dataset. There may also be opportunities for further refined analyses of firms operating in different industries with distinct environmental characteristics, such as, capital-intensive and 
knowledge-intensive service industries, to uncover new relevant insights about effective internationalization processes (Contractor, Kundu and Hsu, 2003).

\section{CONCLUSIONS}

The results of this study based on analyses of a large cross sectional sample of firms demonstrate that multinationality has a positive association with economic performance and generally is enhanced by lower financial leverage. However, there is no evidence of a direct positive risk management effect from multinational enterprise. The findings suggest that firms operating in dynamic global environments should take capital structure decisions into account when they pursue international expansion. However, the results also point toward further needs to study how effective risk management may facilitate successful internationalization processes. 


\section{REFERENCES}

Aldrich HE. 1999. Organizations Evolving. Newbury Park, CA, Sage.

Aldrich HE, Auster E. 1986. Even dwarfs started small: Liabilities of age and size and their strategic implications, in Staw B, Cummings, LL (eds.). Research in Organizational Behavior, VIII. Grenwich, CT, JAI Press.

Allen L, Pantzalis C. 1996. Valuation of the operating flexibility of multinational corporations. Journal of International Business Studies 27: 633-653.

Andersen TJ, Foss N. 2005. Strategic opportunity and economic performance in multinational enterprise: The role and effects of information and communication technology. Journal of International Management 11: 293-310.

Balakrisnan S, Fox I. 1993. Asset specificity, firm heterogeneity and capital structure. Strategic Management Journal 14: 3-16.

Banerjee S, Wihlborg C. 2003. Irreversibilities, assets specificity and capital structure. Working Paper, Copenhagen Business School.

Barney JB. 1991. Firm resources and sustained competitive advantage. Journal of Management 17: 99120.

Bartlett CA, Ghoshal S. 1998. Managing Across Borders: The Transnational Solution $2^{\text {nd }}$ ed. London, Random House.

Barton SL, Gordon PJ. 1987. Corporate strategy: useful perspectives for the study of capital structure. Academy of Management Review 12: 67-75.

Barton SL, Gordon PJ. 1988. Corporate strategy and capital structure. Strategic Management Journal 9: 623-632.

Berger P, Ofek E, Yermack D. 1997. Managerial entrenchment and capital structure decisions. Journal of Finance, 52: 1411-1438.

Bettis RA, Hitt MA. 1995. The new competitive landscape. Strategic Management Journal 16: 7-19.

Bowman EH, Hurry D. 1993. Strategy through the option lens: an integrated view of resource investments and the incremental-choice process. Academy of Management Review 18: 760-782.

Bradley M, Jarrell GA, Kim EH. 1984. On the existence of an optimal capital structure: theory and evidence. Journal of Finance 39: 857-878.

Christophe SE. 1996. Hysteresis and the value of the U.S. multinational corporation, Journal of Business 75: 67-93.

Chung KH. 1993. Asset characteristics and corporate debt policy: An empirical test. Journal of Business Finance 20: 83-98. 
Colarossi, D. (2000). Capitalizing on innovation in the use of contingent capital. Swiss Re New Markets, New York.

Contractor FJ, Kundu SK, Hsu CA. 2003. Three-stage theory of international expansion: The link between multinationality and performance in the service sector. Journal of International Business Studies 34: 5-19.

Culp CL. 2002. The ART of Risk Management: Alternative Risk Transfer, Capital Structure, and the Convergence of Insurance and Capital Markets. Wiley, New York.

Davis R, Duhaime IM. 1992. Diversification, vertical integration, and industry analysis: new perspectives and measurement. Strategic Management Journal 13: 511-524.

D’Aveni R. 1994. Hypercompetition. New York, Free Press.

DeAngelo H, Masulis R. 1980. Optimal capital structure under corporate and personal taxation. Journal of Financial Economics 8: 3-29.

Dess GG, Beard DW. 1984. Dimensions of organizational task environments. Administrative Science Quarterly 29: 52-73.

Desouza K, Evaristo R. 2003. Global knowledge management strategies. European Management Journal 21: 62-67.

Dierickx I, Cool K. 1989. Asset stock accumulation and sustainability of competitive advantage. Management Science 35: 1504-1511.

Dixit A, Pindyck RS. 1994. Investment Under Uncertainty. New Jersey, Princeton University Press.

Fama EF, French KR. 1992. The cross-section of expected stock returns. Journal of Finance 47: 427465.

Fama EF, French KR. 1993. Common risk factors in returns on stocks and bonds. Journal of Financial Economics 33: 3-56.

Foss NJ, Pedersen T. 2002. Transferring knowledge in MNCs: The role of subsidiary knowledge and organizational context. Journal of International Management 8: 49-67.

Froot KA, Scharfstein DS, Stein JC. 1993. Risk management: coordinating corporate investment and financiang policies. Journal of Finance 48: 1629-1658.

Froot KA, Scharfstein DS, Stein JC. 1994. A framework for risk management. Harvard Business Review 72(6): 91-102.

Gardner JC, Trzcinka CA. 1992. All-equity firms and the balancing theory of capital structure. Journal of Financial Research 15: 77-90.

Ghosh DK. 1992. Optimum capital structure redefined. Financial Review 27: 411-429.

Govingarajan V, Gupta AK. 2001. The quest for global dominance: Transforming global presence 
into global competitive advantage. San Francisco, Jossey-Bass.

Grant RM. 1996. Toward a knowledge-based theory of the firm. Strategic Management Journal 17: 109-122.

Harris M, Raviv A. 1991. The theory of capital structure. Journal of Finance 46: 297-355.

Hovakimian A, Opler T, Titman S. 2001. The debt-equity choice. Journal of Financial and Quantitative Analysis 36: 1-24.

Jensen MC. 1986. Agency costs of free cash flow, corporate finance, and takeovers. American Economic Review 76: 323-329.

Jensen MC. 1989. Eclipse of the public corporation. Harvard Business Review. 67 (5): 61-74.

Jensen MC, Meckling WH. 1976. Theory of the firm: managerial behavior, agency costs and ownership structure. Journal of Financial Economics 76: 323-329.

Keats BW, Hitt MA. 1988. A causal model of linkages among environmental dimensions, macro organizational characteristics, and performance. Academy of Management Journal 31: 570-598.

Kleinbaum DG, Kupper LK, Mullerm KE, Nizam A. 1998. Applied Regression Analysis and Other Multivariate Methods $3^{\text {rd }}$ ed. Pacific Grove, CA, Duxbury Press.

Kochar R. 1996. Explaining firm capital structure: The role of agency theory vs. transaction cost economics. Strategic Management Journal 17: 713-728.

Kochar R, Hitt MA. 1998. Linking corporate strategy to capital structure: diversification strategy, type and source of financing. Strategic Management Journal 19: 601-610.

Kogut B. 1985. Designing global strategies: Profiting from operational flexibility. MIT Sloan Management Review 27(4): 27-38.

Kogut B, Chang SJ. 1996. Platform investments and volatile exchange rates: Direct investment in the U.S. by Japanese electronic companies. Review of Economics and Statistics 78: 221-231.

Kogut B, Kulatilaka N. 1994. Operating flexibility, global manufacturing and the option value of a multinational network. Management Science 40: 123-138.

Kogut B, Singh H. 1988. The effect of national culture on the choice of entry mode. Journal of International Business Studies 19: 411-432.

Kogut B, Zander U. 1992. Knowledge of the firm, combinative capabilities, and the replication of technology. Organization Science 3:383-397.

Kogut B, Zander U. 1993. Knowledge of the firm and the evolutionary theory of the multinational corporation. Journal of International Business Studies 15: 151-168.

Leiblein MJ. 2003. The choice of organizational governance form and performance: Predictions from transaction cost, resource-based, and real options theories. Journal of Management 29: 937-961. 
Leuhrman TA. 1998. Investment opportunities as real options: Getting started on the numbers. Harvard Business Review 76(4): 51-67.

Lomax RG. 1992. Statistical Concepts: A Second Course for Education and the Behavioral Sciences. Longman, New York.

Mang PL. 1998. Exploiting innovation options: An empirical analysis of R\&D intensive firms. Journal of Economic Behavior and Organization 35: 229-242.

McGrath RG. 1997. A real options logic for initiating technology positioning investments. Academy of Management Review 22: 974-996.

McGrath RG, Nerkar A. 2004. Real options reasoning and a new look at the R\&D investment strategies of pharmaceutical firms. Strategic Management Journal 25: 1-21.

Miller KD. 1998. Economic exposure and integrated risk management. Strategic Management Journal 19: 497-514.

Modigliani F, Miller MH. 1958. The cost of capital, corporate finance and the theory of investment. American Economic Review 48: 261-297.

Modigliani F, Miller MH. 1963. Corporate income taxes and the cost of capital: a correction. American Economic Review 53: 433-443.

Myers SC. 1977. Determinants of corporate borrowing. Journal of Financial Economics 5: 147-175.

Myers SC. 1984. The capital structure puzzle. Journal of Finance 39: 575-592.

Myers SC, Majluf NS. 1984. Corporate financing and investment decisions when firms have information that investors do not have. Journal of Financial Economics 13: 187-221.

O’Brien JP. 2003. The capital structure implications of pursuing a strategy of innovation. Strategic Management Journal 24: 415-432.

Opler TC, Pinkowitz L, Stulz R, Williamson R. 1999. The determinants and implications of corporate cash holdings. Journal of Financial Economics 52: 3-46.

Opler TC, Titman S. 1994. Financial distress and corporate performance. Journal of Finance 49: 10151040.

Prahalad CK, Doz YL. 1987. The Multinational Mission. New York, Free Press.

Rangan S. 1998. Do multinationals operate flexibly? Theory and evidence. Journal of International Business Studies 29: 217-237.

Rawls SW, Smithson CW. 1990. Strategic risk management. Journal of Applied Corporate Finance 2(2): 6-18. 
Reeb DM, Kwok CCY, Baek HY. 1998. Systematic risk of the multinational corporation. Journal of International Business Studies 29: 263-279.

Reuer JJ, Leiblen MJ. 2000. Downside risk implications of multinationality and international joint ventures. Academy of Management Journal 43: 203-214.

Sandberg CM, Lewellen WG, Stanley KL. 1987. Financial strategy: planning and managing the corporate leverage position. Strategic Management Journal 8: 15-24.

Santarelli E. 1991. Asset specificity, R and D financing, and the signaling properties of the firm's financial structure. Economics of Innovation and New Technology 1: 279-294.

Saunders A, Cornett MM. 2003. Financial Institutions Management: Risk Management Approach $3^{\text {rd }}$ ed. McGraw-Hill Irwin, New York.

Shimpi PA. 1999. Integrating risk management and capital management, in Shimpi PA. (Ed.) Integrating Corporate Risk Management. Swiss Re New Markets, New York.

Simerly RL, Li M. 2000. Environmental dynamism, capital structure and performance: a theoretical integration and an empirical test. Strategic Management Journal 21: 31-50.

Stulz R. 1990. Managerial discretion and optimal financing policies. Journal of Financial Economics 26: 3-27.

Taylor P, Lowe J. 1995. A note on corporate strategy and capital structure. Strategic Management Journal 16: 411-414.

Thies CF, Klock MS. 1992. Determinants of capital structure. Review of Financial Economics 1: 40-52.

Thomas LG. 1996. Dynamic resourcefulness and the hypercompetitive shift. Organization Science 7: 221-242.

Titman S, Wessels R. 1988. The determinants of capital structure choice. Journal of Finance 43: 1-19. Ward K. 1993. Corporate Financial Strategy. Butterworth Heinemann, Oxford, UK.

Williamson O. 1988. Corporate finance and corporate governance. Journal of Finance 43: 567-591.

Zaheer S. 1995. Overcoming the Liabilities of Foreignness. Academy of Management Journal 38: 341363. 


\section{Table 1. Descriptive Statistics and Correlation Coefficients ${ }^{\mathrm{a}}$}

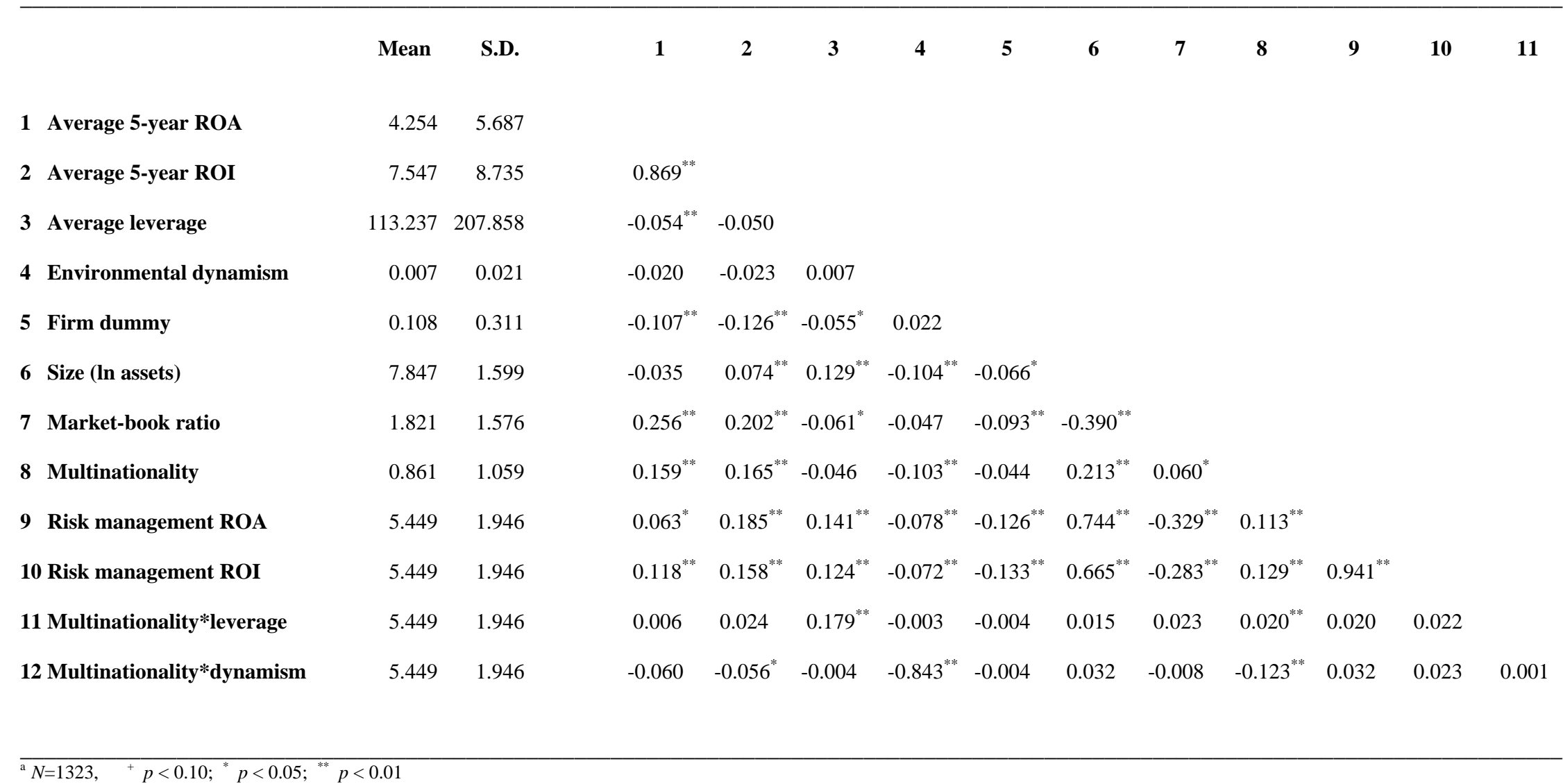


Table 2. Multiple Regression Analyses ${ }^{\mathrm{a}}$ [Standardized Regression Coefficients]

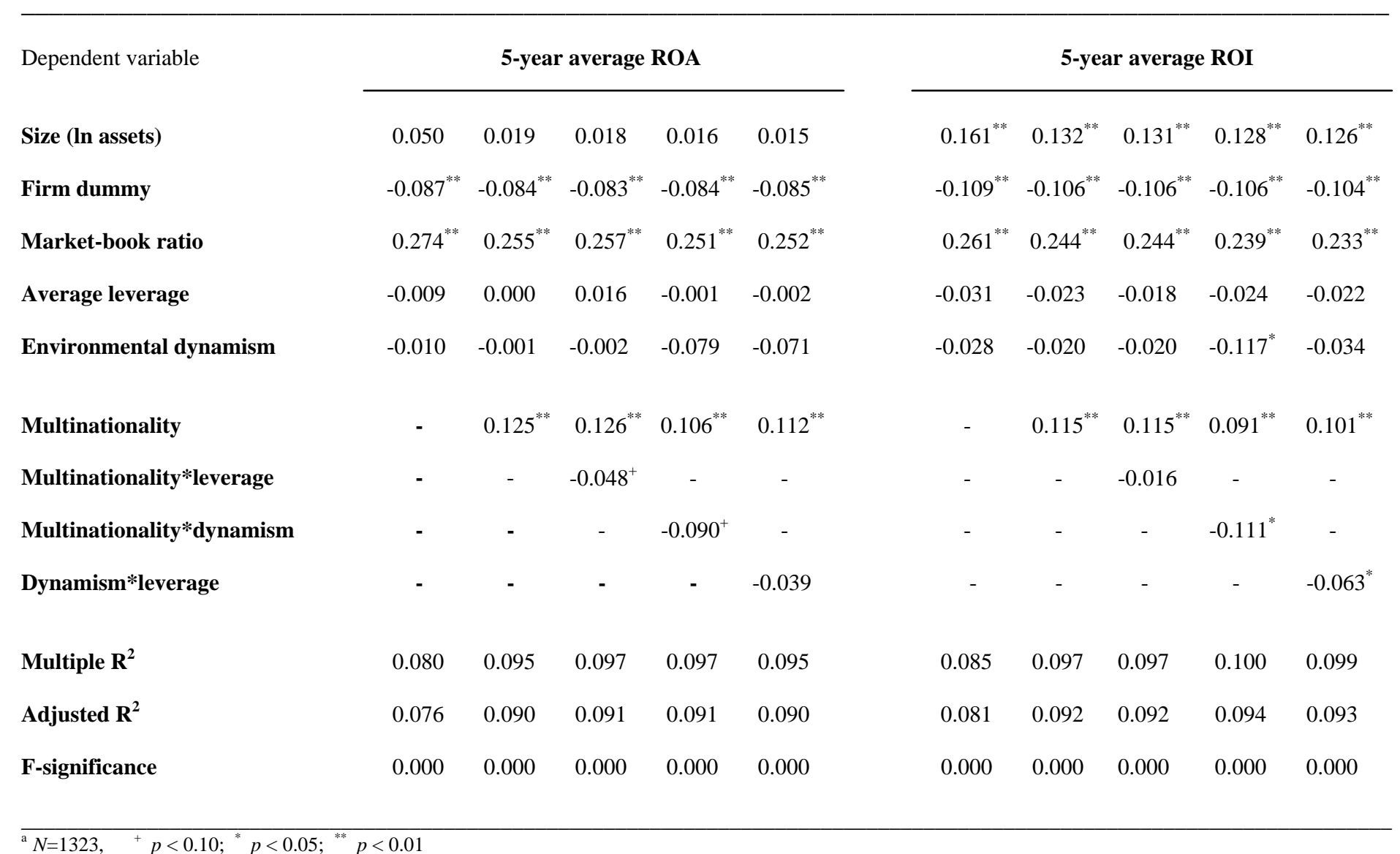


Table 3. Multiple Regression Analyses ${ }^{\mathrm{a}}$ [Standardized Regression Coefficients]

\begin{tabular}{|c|c|c|c|c|c|c|c|c|}
\hline \multirow{2}{*}{$\begin{array}{l}\text { Dependent variable } \\
\text { Size (ln assets) }\end{array}$} & \multicolumn{4}{|c|}{ Risk management ROA } & \multicolumn{4}{|c|}{ Risk management ROI } \\
\hline & $0.704^{* *}$ & $0.714^{* *}$ & $0.714^{* *}$ & $0.714^{* *}$ & $0.624^{* *}$ & $0.629^{* *}$ & $0.629^{* *}$ & $0.628^{* *}$ \\
\hline Firm dummy & $-0.083^{* *}$ & $-0.084^{* *}$ & $-0.084^{* *}$ & $-0.084^{* *}$ & $-0.100^{* *}$ & $-0.100^{* *}$ & $-0.100^{* *}$ & $-0.100^{* *}$ \\
\hline Market-book ratio & $-0.057^{* *}$ & $-0.051^{*}$ & $-0.051^{*}$ & $-0.052^{*}$ & $-0.044^{+}$ & $-0.041^{+}$ & $-0.042^{+}$ & $-0.042^{+}$ \\
\hline Average leverage & $-0.040^{*}$ & $-0.037^{+}$ & $-0.037^{+}$ & $-0.037^{+}$ & -0.033 & -0.032 & -0.028 & -0.031 \\
\hline Environmental dynamism & -0.012 & -0.014 & -0.014 & -0.026 & 0.000 & -0.001 & -0.001 & -0.019 \\
\hline Multinationality & - & $-0.041^{*}$ & $-0.041^{*}$ & $-0.043^{*}$ & - & -0.020 & -0.021 & -0.025 \\
\hline Multinationality*leverage & - & - & 0.002 & - & - & - & 0.011 & - \\
\hline Multinationality*dynamism & - & - & - & -0.013 & - & - & - & -0.020 \\
\hline Multiple $\mathbf{R}^{2}$ & 0.560 & 0.562 & 0.562 & 0.562 & 0.442 & 0.442 & 0.443 & 0.443 \\
\hline Adjusted $\mathbf{R}^{2}$ & 0.559 & 0.560 & 0.559 & 0.559 & 0.440 & 0.440 & 0.439 & 0.439 \\
\hline F-significance & 0.000 & 0.000 & 0.000 & 0.000 & 0.000 & 0.000 & 0.000 & 0.000 \\
\hline
\end{tabular}




\section{SMG - Working Papers \\ www.cbs.dk/smg \\ 2003}

2003-1: Nicolai J. Foss, Kenneth Husted, Snejina Michailova, and Torben Pedersen: Governing Knowledge Processes: Theoretical Foundations and Research Opportunities.

2003-2: Yves Doz, Nicolai J. Foss, Stefanie Lenway, Marjorie Lyles, Silvia Massini, Thomas P. Murtha and Torben Pedersen: Future Frontiers in International Management Research: Innovation, Knowledge Creation, and Change in Multinational Companies.

2003-3: Snejina Michailova and Kate Hutchings: The Impact of In-Groups and OutGroups on Knowledge Sharing in Russia and China CKG Working Paper.

2003-4: Nicolai J. Foss and Torben Pedersen : The MNC as a Knowledge Structure: The Roles of Knowledge Sources and Organizational Instruments in MNC Knowledge Management CKG Working Paper.

2003-5: Kirsten Foss, Nicolai J. Foss and Xosé H. Vázquez-Vicente: “Tying the Manager's Hands": How Firms Can Make Credible Commitments That Make Opportunistic Managerial Intervention Less Likely CKG Working Paper.

2003-6: Marjorie Lyles, Torben Pedersen and Bent Petersen: Knowledge Gaps: The Case of Knowledge about Foreign Entry.

2003-7: Kirsten Foss and Nicolai J. Foss: The Limits to Designed Orders: Authority under "Distributed Knowledge" CKG Working Paper.

2003-8: Jens Gammelgaard and Torben Pedersen: Internal versus External Knowledge Sourcing of Subsidiaries - An Organizational Trade-Off.

2003-9: Kate Hutchings and Snejina Michailova: Facilitating Knowledge Sharing in Russian and Chinese Subsidiaries: The Importance of Groups and Personal Networks Accepted for publication in Journal of Knowledge Management.

2003-10: Volker Mahnke, Torben Pedersen and Markus Verzin: The Impact of Knowledge Management on MNC Subsidiary Performance: the Role of Absorptive Capacity CKG Working Paper.

2003-11: Tomas Hellström and Kenneth Husted: Mapping Knowledge and Intellectual Capital in Academic Environments: A Focus Group Study Accepted for publication in Journal of Intellectual Capital CKG Working Paper.

2003-12: Nicolai J Foss: Cognition and Motivation in the Theory of the Firm: Interaction or "Never the Twain Shall Meet"? Accepted for publication in Journal des Economistes et des Etudes Humaines CKG Working Paper.

2003-13: Dana Minbaeva and Snejina Michailova: Knowledge Transfer and Expatriation Practices in MNCs: The Role of Disseminative Capacity.

2003-14: Christian Vintergaard and Kenneth Husted: Enhancing Selective Capacity Through Venture Bases. 


\section{4}

2004-1: Nicolai J. Foss: Knowledge and Organization in the Theory of the Multinational Corporation: Some Foundational Issues

2004-2: Dana B. Minbaeva: HRM Practices and MNC Knowledge Transfer

2004-3: Bo Bernhard Nielsen and Snejina Michailova: Toward a Phase-Model of Global Knowledge Management Systems in Multinational Corporations

2004-4: Kirsten Foss \& Nicolai J Foss: The Next Step in the Evolution of the RBV: Integration with Transaction Cost Economics

2004-5: Teppo Felin \& Nicolai J. Foss: Methodological Individualism and the Organizational Capabilities Approach

2004-6: Jens Gammelgaard, Kenneth Husted, Snejina Michailova: Knowledge-sharing Behavior and Post-acquisition Integration Failure

2004-7: Jens Gammelgaard: Multinational Exploration of Acquired R\&D Activities

2004-8: Christoph Dörrenbächer \& Jens Gammelgaard: Subsidiary Upgrading? Strategic Inertia in the Development of German-owned Subsidiaries in Hungary

2004-9: Kirsten Foss \& Nicolai J. Foss: Resources and Transaction Costs: How the Economics of Property Rights Furthers the Resource-based View

2004-10: Jens Gammelgaard \& Thomas Ritter: The Knowledge Retrieval Matrix: Codification and Personification as Separate Strategies

2004-11: Nicolai J. Foss \& Peter G. Klein: Entrepreneurship and the Economic Theory of the Firm: Any Gains from Trade?

2004-12: Akshey Gupta \& Snejina Michailova: Knowledge Sharing in Knowledge-Intensive Firms: Opportunities and Limitations of Knowledge Codification

2004-13: Snejina Michailova \& Kate Hutchings: Knowledge Sharing and National Culture: A Comparison Between China and Russia

\section{5}

2005-1: Keld Laursen \& Ammon Salter: My Precious - The Role of Appropriability Strategies in Shaping Innovative Performance

2005-2: Nicolai J. Foss \& Peter G. Klein: The Theory of the Firm and Its Critics: A Stocktaking and Assessment

2005-3: Lars Bo Jeppesen \& Lars Frederiksen: Why Firm-Established User Communities Work for Innovation: The Personal Attributes of Innovative Users in the Case of Computer-Controlled Music

2005-4: Dana B. Minbaeva: Negative Impact of HRM Complementarity on Knowledge Transfer in MNCs

2005-5: Kirsten Foss, Nicolai J. Foss, Peter G. Klein \& Sandra K. Klein: Austrian Capital 
Theory and the Link Between Entrepreneurship and the Theory of the Firm

2005-1: Nicolai J. Foss: The Knowledge Governance Approach

2005-2: Torben J. Andersen: Capital Structure, Environmental Dynamism, Innovation Strategy, and Strategic Risk Management

2005-3: Torben J. Andersen: A Strategic Risk Management Framework for Multinational Enterprise

2005-4: Peter Holdt Christensen: Facilitating Knowledge Sharing: A Conceptual Framework

2005-5 Kirsten Foss \& Nicolai J. Foss: Hands Off! How Organizational Design Can Make Delegation Credible

2005-6 Marjorie A. Lyles, Torben Pedersen \& Bent Petersen: Closing the Knowledge Gap in Foreign Markets - A Learning Perspective

2005-7 Christian Geisler Asmussen, Torben Pedersen \& Bent Petersen: How do we Capture "Global Specialization" when Measuring Firms' Degree of internationalization?

2005-8 Kirsten Foss \& Nicolai J. Foss: Simon on Problem-Solving: Implications for New Organizational Forms

2005-9 Birgitte Grøgaard, Carmine Gioia \& Gabriel R.G. Benito: An Empirical Investigation of the Role of Industry Factors in the Internationalization Patterns of Firms

2005-10 Torben J. Andersen: The Performance and Risk Management Implications of Multinationality: An Industry Perspective

2005-11 Nicolai J. Foss: The Scientific Progress in Strategic Management: The case of the Resource-based view

2005-12 Koen H. Heimeriks: Alliance Capability as a Mediator Between Experience and Alliance Performance: An Empirical Investigation Into the Alliance Capability Development Process

2005-13 Koen H. Heimeriks, Geert Duysters \& Wim Vanhaverbeke: Developing Alliance Capabilities: An Empirical Study

2005-14 JC Spender: Management, Rational or Creative? A Knowledge-Based Discussion

\section{6}

2006-1: Nicolai J. Foss \& Peter G. Klein: The Emergence of the Modern Theory of the Firm

2006-2: Teppo Felin \& Nicolai J. Foss: Individuals and Organizations: Thoughts on a Micro-Foundations Project for Strategic Management and Organizational Analysis

2006-3: Volker Mahnke, Torben Pedersen \& Markus Venzin: Does Knowledge Sharing 
Pay? An MNC Subsidiary Perspective on Knowledge Outflows

2006-4: Torben Pedersen: Determining Factors of Subsidiary Development

2006-5 Ibuki Ishikawa: The Source of Competitive Advantage and Entrepreneurial Judgment in the RBV: Insights from the Austrian School Perspective

2006-6 Nicolai J. Foss \& Ibuki Ishikawa: Towards a Dynamic Resource-Based View: Insights from Austrian Capital and Entrepreneurship Theory

2006-7 Kirsten Foss \& Nicolai J. Foss: Entrepreneurship, Transaction Costs, and Resource Attributes

2006-8 Kirsten Foss, Nicolai J. Foss \& Peter G. Klein: Original and Derived Judgement: An Entrepreneurial Theory of Economic Organization

2006-9 Mia Reinholt: No More Polarization, Please! Towards a More Nuanced Perspective on Motivation in Organizations

2006-10 Angelika Lindstrand, Sara Melen \& Emilia Rovira: Turning social capital into business? A study of Swedish biotech firms' international expansion

2006-11 Christian Geisler Asmussen, Torben Pedersen \& Charles Dhanaraj: Evolution of Subsidiary Competences: Extending the Diamond Network Model

2006-12 John Holt, William R. Purcell, Sidney J. Gray \& Torben Pedersen: Decision Factors Influencing MNEs Regional Headquarters Location Selection Strategies

2006-13 Peter Maskell, Torben Pedersen, Bent Petersen \& Jens Dick-Nielsen: Learning Paths to Offshore Outsourcing - From Cost Reduction to Knowledge Seeking

2006-14 Christian Geisler Asmussen: Local, Regional or Global? Quantifying MNC Geographic Scope

2006-15 Christian Bjørnskov \& Nicolai J. Foss: Economic Freedom and Entrepreneurial Activity: Some Cross-Country Evidence

2006-16 Nicolai J. Foss \& Giampaolo Garzarelli: Institutions as Knowledge Capital: Ludwig M. Lachmann's Interpretative Institutionalism

2006-17 Koen H. Heimriks \& Jeffrey J. Reuer: How to Build Alliance Capabilities

2006-18 Nicolai J. Foss, Peter G. Klein, Yasemin Y. Kor \& Joseph T. Mahoney: Entrepreneurship, Subjectivism, and the Resource - Based View: Towards a New Synthesis

2006-19 Steven Globerman \& Bo B. Nielsen: Equity Versus Non-Equity International Strategic Alliances: The Role of Host Country Governance

\section{7}

2007-1 Peter Abell, Teppo Felin \& Nicolai J. Foss: Building Micro-Foundations for the Routines, Capabilities, and Performance Links 
2007-2 Michael W. Hansen, Torben Pedersen \& Bent Petersen: MNC Strategies and Linkage Effects in Developing Countries

2007-3 Niron Hashai, Christian G. Asmussen, Gabriel R.G. Benito \& Bent Petersen: Predicting the Diversity of Foreign Entry Modes

2007-4 Peter D. Ørberg Jensen \& Torben Pedersen: Whether and What to Offshore?

2007-5 Ram Mudambi \& Torben Pedersen: Agency Theory and Resource Dependency Theory: Complementary Explanations for Subsidiary Power in Multinational Corporations

2007-6 Nicolai J. Foss: Strategic Belief Management

2007-7 Nicolai J. Foss: Theory of Science Perspectives on Strategic Management Research: Debates and a Novel View

2007-8 Dana B. Minbaeva: HRM Practices and Knowledge Transfer in MNCs

2007-9 Nicolai J. Foss: Knowledge Governance in a Dynamic Global Context: The Center for Strategic Management and Globalization at the Copenhagen Business School

2007-10 Paola Gritti \& Nicolai J. Foss: Customer Satisfaction and Competencies: An Econometric Study of an Italian Bank

2007-11 Nicolai J. Foss \& Peter G. Klein: Organizational Governance

2007-12 Torben Juul Andersen \& Bo Berhard Nielsen: The Effective Ambidextrous Organization: A Model of Integrative Strategy Making Processes.

\section{8}

2008-1 Kirsten Foss \& Nicolai J. Foss: Managerial Authority When Knowledge is Distributed: A Knowledge Governance Perspective

2008-2 Nicolai J. Foss: Human Capital and Transaction Cost Economics.

2008-3 Nicolai J. Foss \& Peter G. Klein: Entrepreneurship and Heterogeneous Capital.

2008-4 Nicolai J. Foss \& Peter G. Klein: The Need for an Entrepreneurial Theory of the Firm.

2008-5 Nicolai J. Foss \& Peter G. Klein: Entrepreneurship: From Opportunity Discovery to Judgment.

2008-6 Mie Harder: How do Rewards and Management Styles Influence the Motivation to Share Knowledge?

2008-7 Bent Petersen, Lawrence S. Welch \& Gabriel R.G. Benito: Managing the Internalisation Process - A Theoretical Perspective.

2008-8 Torben Juul Andersen: Multinational Performance and Risk Management Effects: Capital Structure Contingencies. 